\title{
Prognozowanie stanu zużycia klocka hamulcowego na podstawie parametrów sygnału akustycznego
}

\begin{abstract}
$W$ artykule przedstawiono wyniki badań symulacyjnych i stanowiskowych pary ciernej koto-klocek. Porównano widma akustyczne dla klocków o różnej grubości. Wskazano na eksploatacyjne aspekty poprawnej diagnostyki zużycia klocków hamulcowych.

Artykut powstat $w$ wyniku realizacji projektu rozwojowego $n r \quad R \quad 10$ 004806/2009 pt. ,,Mikroprocesorowy system diagnostyczny głównych systemów trakcyjnego pojazdu szynowego uwzględniajacy ocene bieżaca $i$ prognozowanie stanów", finansowanego z budżetu Ministerstwa Nauki $i$ Szkolnictwa Wyższego.
\end{abstract}

\section{Cel pracy}

Celem pracy jest opracowanie metodyki diagnostycznej zużycia klocków hamulcowych pojazdów szynowych za pomocą modelu numerycznego pary ciernej koło-klocek przy możliwie najwierniejszym odzwierciedleniu rzeczywistych zjawisk fizycznych oraz weryfikacja tego modelu numerycznego badaniami stanowiskowymi i określenie wpływu parametrów pracy tego układu na emitowaną falę akustyczną.

\subsection{Wprowadzenie}

Artykuł jest podsumowaniem etapów pracy opisanych w OR-9789, OR-9804, OR-9967, OR-9981, OR-10006, OR-10042 i OR-10220. Częstym problemem spotykanym w eksploatacji pojazdów szynowych jest ocena stanu zużycia klocków hamulcowych. Zazwyczaj dokonuje się jej wizualnie a skutkami ewentualnych niedopatrzeń są nadmierne wytarcie klocka a w efekcie pogorszenie skuteczności hamowania i zniszczenie powierzchni tocznej koła w wyniku kontaktu z twardą powierzchnią obsady. Przykłady konsekwencji błędów popełnionych przy eksploatacji klocków przedstawiono na rys. 1 i 2 (były to zjawiska zaobserwowane podczas prawie dwuletniej eksploatacji wagonów 430W prowadzonej przez IPS „TABOR")

Istotną rzeczą jest, więc znalezienie sposobu diagnozowania stanu zużycia klocków hamulcowych i wprowadzenie jej do bieżącej eksploatacji. Niewątpliwym ułatwieniem byłaby możliwość prognozowania stanu zużycia powierzchni ciernej klocka na podstawie analizy fali akustycznej w trakcie hamowania $\mathrm{i}$ określenie bieżącego zużycia klocków hamulcowych.
Koncepcja ta bazuje na prostej obserwacji eksperymentalnej wskazującej wpływ grubości klocka na amplitudę i częstotliwość generowanej podczas hamowania fali akustycznej.

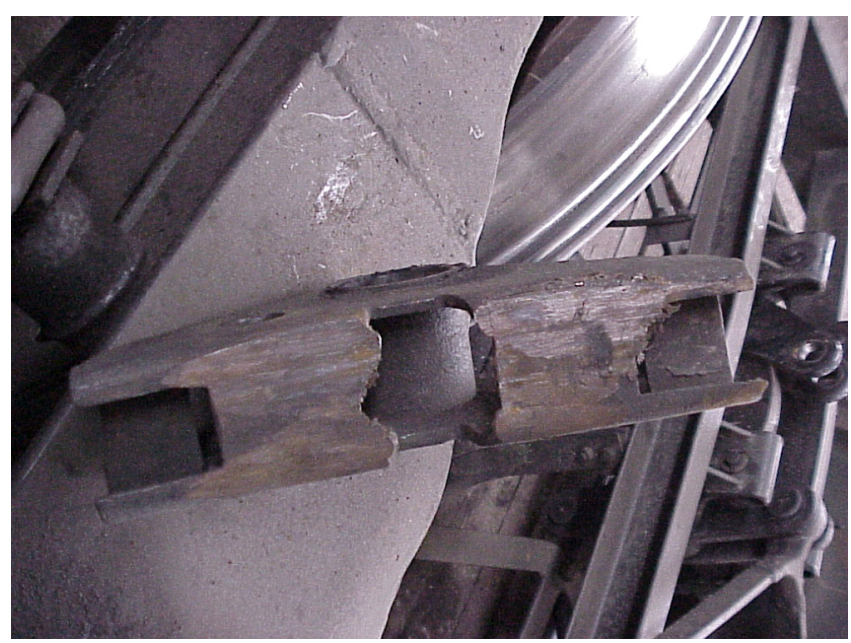

Rys. 1. Całkowite zużycie powierzchni ciernej klocka i jego wypadnięcie. Hamowanie odbywało się obsadą.

\subsection{Metodologia rozwiązania zagadnienia}

Metodyka rozwiązania zagadnienia emisji fali akustycznej przez współpracującą parę cierną wymaga znajomości fizycznej interpretacji tego zjawiska. Fala akustyczna powstaje w efekcie ścierania się nierówności powierzchni ciernej klocka i powierzchni tocznej koła, które powoduje ich wzajemne pobudzanie do 


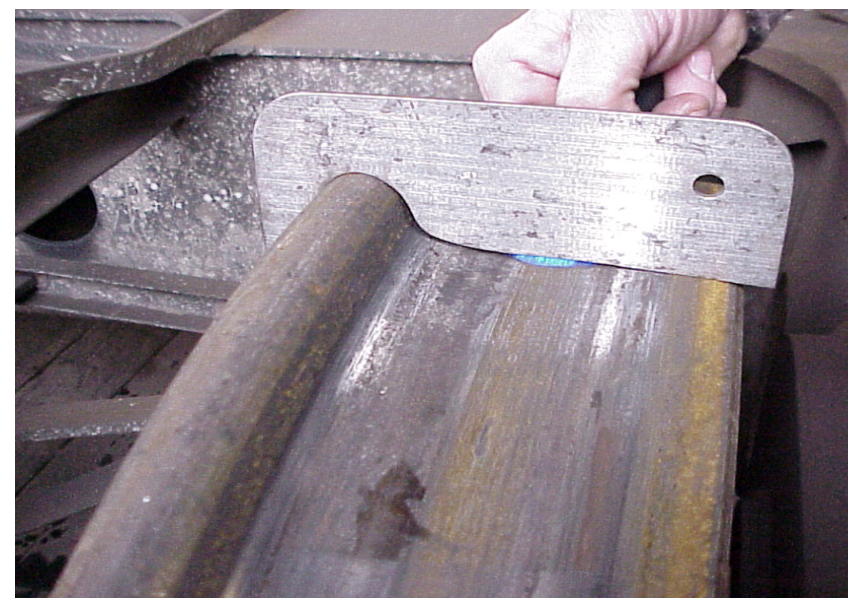

Rys. 2. Uszkodzenie powierzchni tocznej koła spowodowane nadmiernym zużyciem klocka i hamowaniem klinem (widoczne wgłębienie pod przymiarem AOC)

drgań, przenoszonych następnie przez powietrze i odbieranych, jako dźwięk. Towarzyszy temu szereg zjawisk dodatkowych jak np.: rozgrzewanie pary ciernej, ubytki materiału powodujące zmiany rzeczywistych stref kontaktu pomiędzy klockiem a kołem, tłumienność materiału itd. Ze względu na złożoność badanego zjawiska nieodzowne było równoczesne przeprowadzenie eksperymentalnych prób stanowiskowych stanowiących dalszą podstawę do konstrukcji modelu numerycznego. Jako środowisko jego konstrukcji wybrano program mesowski Abaqus. Na słuszność takiej koncepcji rozwiązania wskazują załączone pozycje literaturowe [1], [2], [3] i [4] w których autorzy zgodnie uznają trafność podejścia metodą elementów skończonych do rozwiązywania zagadnień związanych z emisją fali akustycznej.

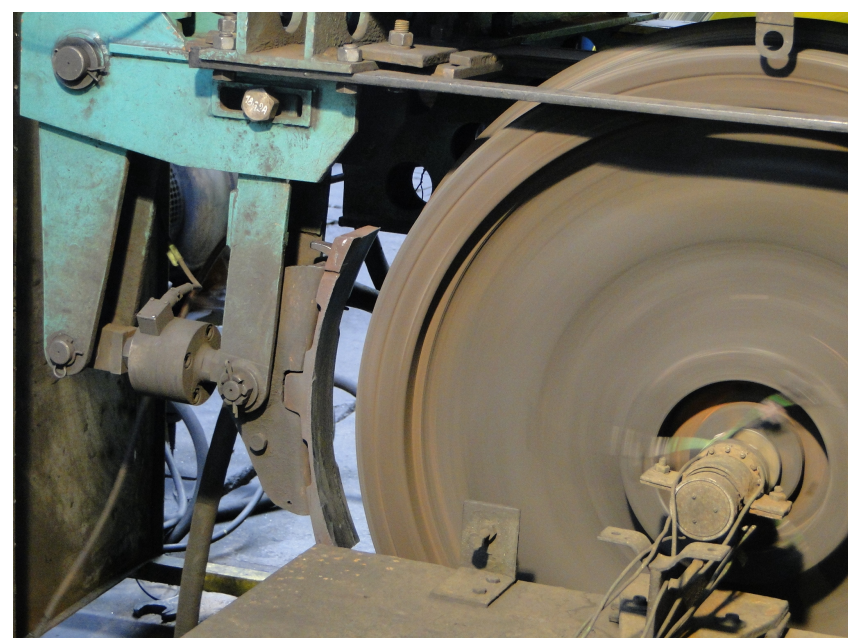

Rys. 3. Wygląd stanowiska badawczego podczas próby hamowania (klocek hamulcowy o granicznym zużyciu)

\subsection{Osiągnięte wyniki prób stanowiskowych}

Wszystkie próby przeprowadzono na stanowisku 12 SB znajdującym się w IPS Tabor. Stanowisko to służy do wykonywania badań układów hamulcowych $\mathrm{z}$ uwzględnieniem $\mathrm{w}$ skali 1:1 bezwładności masy pojazdu szynowego. Widok stanowiska pomiarowego przedstawiono na rys. 3 .

Aparaturę pomiarową $\mathrm{w}$ postaci mikrofonu $1 / 2$ " firmy Bruel \& Kjær typu 4133 o charakterystyce dookólnej ustawiono w odległości $1,5 \mathrm{~m}$ od miejsca styku koło-klocek na wysokości środka klocka. Rejestrowane wartości poziomu dźwięku zapisano na dysku twardym komputera za pomocą licencjonowanego programu PULSE Recorder firmy Bruel \& Kjær. Zastosowana aparatura umożliwiła zarejestrowanie sygnału w paśmie do $20000 \mathrm{~Hz}$.

Przedmiotem rozważań było wyznaczenie widma akustycznego podczas prób hamowania dla różnych konfiguracji materiału klocka, grubości klocka i prędkości początkowej.

Próby wykonano dla dwóch rodzajów materiału klocków hamulcowych, przy uwzględnieniu trzech różnych grubości w obrębie każdego $\mathrm{z}$ nich:

- dla klocka P10 (grubości średnie):

$$
\begin{aligned}
& 56,6 \mathrm{~mm} \text {, } \\
& 28,9 \mathrm{~mm} \\
& 18,8 \mathrm{~mm}
\end{aligned}
$$

- dla klocka kompozytowego LL FR-510 (grubości średnie):

$$
\begin{aligned}
& 42,4 \mathrm{~mm} \\
& 32,1 \mathrm{~mm} \\
& 23,2 \mathrm{~mm}
\end{aligned}
$$

Rozpatrzono dwie początkowe prędkości hamowania $80 \mathrm{~km} / \mathrm{h}$ i $60 \mathrm{~km} / \mathrm{h}$ a uzyskane dla nich wyniki pomiarów przedstawiono w Tabelach 1 i 2 . Przed przystąpieniem do pomiarów widma podczas procesu hamowania zmierzono tło akustyczne stanowiska (uruchomione stanowisko $12 \mathrm{SB} \mathrm{z}$ obracającym się bez hamowania kołem i masą bezwładnościową odpowiadającą obciążeniu 20t/oś)

Ze względu na powszechność stosowania w eksploatacji starszego taboru kolejowego klocków hamulcowych P10 oraz dużo niższego poziomu widma akustycznego (w porównaniu z widmem tła) dalszą analizę problemu oparto o wyniki uzyskane dla klocków hamulcowych P10.

$\mathrm{Na}$ podstawie powyższych tabel sporządzono wykresy 4 i 5 przedstawiające zależności amplitudy widma akustycznego A [dB] w zależności od częstotliwości f [Hz]. 


\begin{tabular}{|c|c|c|c|c|c|c|c|c|c|c|c|c|c|}
\hline \multirow[t]{2}{*}{$\begin{array}{c}\mathrm{F} \\
{[\mathrm{Hz}]}\end{array}$} & \multirow[t]{2}{*}{$\left|\begin{array}{c}\text { Tło } \\
80 \mathrm{~km} / \mathrm{h}\end{array}\right|$} & \multicolumn{3}{|c|}{$\begin{array}{c}\text { Pomiary } \\
{[\mathrm{dB}]}\end{array}$} & \multirow{2}{*}{$\begin{array}{c}\begin{array}{c}\text { Grubość } \\
\text { klocka } \\
{[\mathrm{mm}]}\end{array} \\
56,6 \\
\end{array}$} & \multicolumn{3}{|c|}{$\begin{array}{c}\text { Pomiary } \\
{[\mathrm{dB}]}\end{array}$} & \multirow{2}{*}{$\begin{array}{c}\begin{array}{c}\text { Grubość } \\
\text { klocka } \\
{[\mathrm{mm}]}\end{array} \\
18,8 \\
\end{array}$} & \multicolumn{3}{|c|}{$\begin{array}{c}\text { Pomiary } \\
{[\mathrm{dB}]}\end{array}$} & \multirow{2}{*}{$\begin{array}{c}\begin{array}{c}\text { Grubość } \\
\text { klocka } \\
\text { [mm] }\end{array} \\
28,9 \\
\end{array}$} \\
\hline & & Pom I & Pom II & Pom III & & Pom I & Pom II & Pom III & & Pom I & Pom II & Pom III & \\
\hline 5000,0 & 36,8 & 63,4 & 63,8 & 68,6 & 28,5 & 60,3 & 60,3 & 63,2 & 24,4 & 68,2 & 67,8 & 68,6 & 31,4 \\
\hline 5003,1 & 37,4 & 64,1 & 64,5 & 68,5 & 28,4 & 61,1 & 61,2 & 63,6 & 24,6 & 68,5 & 68,1 & 69,5 & 31,4 \\
\hline 5006,3 & 36,3 & 65,4 & 65,5 & 68,4 & 30,1 & 61,0 & 60,7 & 61,8 & 24,9 & 67,8 & 69,7 & 69,9 & 32,8 \\
\hline 5009,4 & 37,4 & 65,4 & 65,4 & 70,9 & 29,9 & 61,5 & 61,2 & 61,3 & 24,0 & 68,1 & 70,2 & 68,6 & 31,6 \\
\hline 5012,5 & 37,4 & 66,5 & 65,7 & 72,1 & 30,7 & 62,1 & 63,3 & 61,8 & 25,0 & 66,5 & 67,6 & 68,3 & 30,1 \\
\hline 5015,6 & 36,3 & 66,0 & 66,8 & 71,6 & 31,9 & 62,2 & 63,9 & 64,0 & 27,1 & 66,5 & 68,6 & 69,9 & 32,1 \\
\hline 5018,8 & 38,2 & 67,5 & 67,8 & 71,1 & 30,6 & 62,8 & 63,7 & 65,1 & 25,7 & 67,1 & 70,2 & 69,6 & 30,8 \\
\hline 5021,9 & 38,2 & 67,7 & 67,7 & 70,1 & 30,3 & 62,4 & 63,8 & 63,8 & 25,2 & 66,2 & 69,0 & 68,3 & 29,7 \\
\hline 5025,0 & 38,7 & 66,6 & 66,9 & 68,5 & 28,6 & 63,0 & 63,8 & 63,8 & 24,8 & 63,9 & 69,1 & 69,2 & 28,7 \\
\hline 5028,1 & 37,3 & 65,3 & 66,9 & 69,0 & 29,7 & 63,8 & 63,5 & 64,3 & 26,5 & 65,4 & 70,1 & 68,1 & 30,5 \\
\hline 5031,3 & 38,0 & 64,5 & 66,5 & 70,0 & 29,0 & 63,3 & 63,7 & 63,5 & 25,5 & 65,2 & 69,7 & 67,5 & 29,5 \\
\hline 5034,4 & 37,7 & 64,5 & 65,8 & 68,3 & 28,5 & 62,5 & 62,5 & 63,0 & 25,0 & 65,0 & 68,3 & 67,0 & 29,1 \\
\hline 5037,5 & 37,6 & 63,8 & 64,7 & 67,7 & 27,8 & 61,6 & 62,7 & 63,0 & 24,9 & 64,6 & 67,2 & 67,9 & 29,0 \\
\hline 5040,6 & 37,2 & 64,7 & 65,6 & 67,6 & 28,8 & 63,1 & 63,1 & 64,1 & 26,2 & 64,4 & 66,9 & 66,7 & 28,8 \\
\hline 5043,8 & 36,7 & 64,0 & 65,3 & 67,1 & 28,7 & 62,9 & 64,4 & 64,7 & 27,3 & 62,5 & 66,1 & 67,4 & 28,6 \\
\hline 5046,9 & 38,7 & 64,1 & 64,7 & 67,1 & 26,6 & 61,6 & 63,8 & 64,9 & 24,7 & 63,8 & 64,9 & 67,4 & 26,7 \\
\hline 5050,0 & 38,7 & 64,5 & 64,5 & 66,5 & 26,5 & 59,9 & 61,5 & 63,7 & 23,0 & 64,4 & 66,1 & 66,5 & 26,9 \\
\hline 19946,9 & 15,1 & 50,3 & 50,0 & 48,2 & 34,4 & 55,7 & 53,9 & 57,6 & 40,6 & 52,5 & 51,0 & 50,7 & 36,3 \\
\hline 19950,0 & 14,7 & 51,2 & 49,6 & 49,6 & 35,4 & 56,2 & 54,7 & 57,7 & 41,5 & 51,7 & 51,5 & 50,1 & 36,4 \\
\hline 19953,1 & 16,5 & 50,2 & 49,3 & 48,0 & 32,6 & 55,9 & 54,6 & 56,9 & 39,3 & 50,5 & 51,5 & 49,1 & 33,8 \\
\hline 19956,3 & 16,0 & 49,3 & 49,9 & 47,0 & 32,8 & 55,3 & 55,7 & 57,1 & 40,1 & 51,2 & 50,9 & 48,9 & 34,4 \\
\hline 19959,4 & 16,1 & 50,6 & 50,0 & 48,5 & 33,6 & 55,9 & 55,6 & 57,2 & 40,2 & 51,2 & 49,8 & 50,6 & 34,4 \\
\hline 19962,5 & 15,3 & 50,5 & 49,5 & 48,8 & 34,3 & 56,1 & 55,0 & 57,0 & 40,7 & 50,3 & 50,4 & 48,9 & 34,6 \\
\hline 19965,6 & 16,1 & 50,8 & 51,2 & 49,4 & 34,4 & 55,8 & 54,8 & 57,1 & 39,8 & 51,0 & 50,7 & 49,3 & 34,2 \\
\hline 19968,8 & 16,6 & 50,3 & 50,4 & 48,9 & 33,2 & 56,0 & 55,9 & 57,1 & 39,7 & 51,4 & 49,5 & 49,4 & 33,5 \\
\hline 19971,9 & 15,9 & 50,3 & 49,4 & 49,0 & 33,7 & 56,5 & 55,8 & 57,9 & 40,8 & 50,2 & 50,4 & 49,9 & 34,2 \\
\hline 19975,0 & 16,0 & 51,6 & 49,0 & 48,3 & 33,7 & 56,5 & 53,9 & 57,7 & 40,1 & 51,7 & 50,2 & 48,9 & 34,3 \\
\hline 19978,1 & 16,0 & 51,5 & 49,5 & 48,5 & 33,9 & 55,8 & 53,0 & 56,2 & 39,0 & 52,8 & 49,8 & 50,1 & 34,9 \\
\hline 19981,3 & 14,9 & 50,7 & 48,7 & 49,0 & 34,5 & 56,5 & 54,8 & 55,9 & 40,8 & 53,0 & 49,4 & 50,6 & 36,1 \\
\hline 19984,4 & 16,2 & 49,0 & 48,3 & 49,0 & 32,5 & 56,5 & 55,3 & 56,6 & 39,9 & 52,2 & 49,6 & 50,8 & 34,6 \\
\hline 19987,5 & 16,3 & 47,8 & 51,0 & 48,1 & 32,7 & 56,2 & 54,7 & 58,0 & 40,0 & 51,7 & 50,3 & 49,0 & 34,0 \\
\hline 19990,6 & 16,3 & 49,0 & 50,9 & 49,1 & 33,4 & 55,6 & 55,2 & 56,3 & 39,4 & 51,2 & 50,6 & 48,3 & 33,8 \\
\hline 19993,8 & 16,8 & 49,4 & 49,9 & 48,9 & 32,6 & 55,8 & 55,5 & 55,8 & 38,9 & 52,3 & 49,3 & 49,9 & 33,7 \\
\hline 19996,9 & 17,6 & 50,1 & 49,0 & 48,2 & 31,5 & 55,9 & 55,9 & 56,1 & 38,4 & 51,1 & 49,4 & 50,1 & 32,6 \\
\hline 20000,0 & 16,8 & 50,4 & 49,0 & 49,4 & 32,8 & 54,5 & 55,5 & 55,6 & 38,4 & 51,4 & 49,7 & 50,2 & 33,6 \\
\hline
\end{tabular}

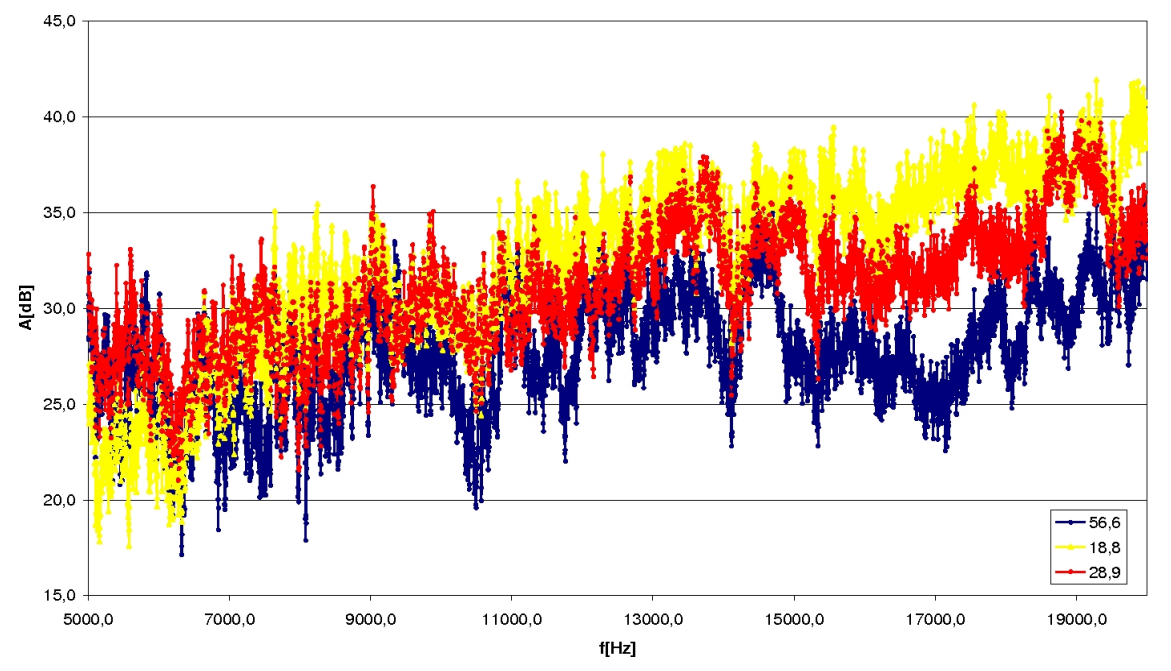

Rys. 4. Widmo akustyczne dla klocka P10 przy prędkości 80 $\mathrm{km} / \mathrm{h}$ 


\begin{tabular}{|c|c|c|c|c|c|c|c|c|c|c|c|c|c|}
\hline \multirow{2}{*}{$\begin{array}{c}\mathrm{F} \\
{[\mathrm{Hz}]}\end{array}$} & \multirow{2}{*}{$\begin{array}{c}\text { Tło } \\
60 \mathrm{~km} / \mathrm{h}\end{array}$} & \multicolumn{3}{|c|}{$\begin{array}{l}\text { Pomiary } \\
{[\mathrm{dB}]}\end{array}$} & \multirow{2}{*}{$\begin{array}{c}\begin{array}{c}\text { Grubość } \\
\text { Klocka } \\
{[\mathrm{mm}]}\end{array} \\
56,6\end{array}$} & \multicolumn{3}{|c|}{$\begin{array}{l}\text { Pomiary } \\
{[\mathrm{dB}]}\end{array}$} & \multirow{2}{*}{$\begin{array}{c}\begin{array}{c}\text { Grubość } \\
\text { Klocka } \\
{[\mathrm{mm}]}\end{array} \\
18,8\end{array}$} & \multicolumn{3}{|c|}{$\begin{array}{l}\text { Pomiary } \\
{[\mathrm{dB}]}\end{array}$} & \multirow{2}{*}{$\begin{array}{c}\begin{array}{c}\text { Grubość } \\
\text { Klocka } \\
{[\mathrm{mm}]}\end{array} \\
28,9\end{array}$} \\
\hline & & Pom I & Pom II & Pom III & & Pom I & Pom II & $\begin{array}{c}\text { Pom } \\
\text { III }\end{array}$ & & Pom I & Pom II & $\begin{array}{c}\text { Pom } \\
\text { III }\end{array}$ & \\
\hline 5000,0 & 34,9 & 60,5 & 62,2 & 61,5 & 26,5 & 58,3 & 60,3 & 62,0 & 25,3 & 66,2 & 70,3 & 67,5 & 33,1 \\
\hline 5003,1 & 35,1 & 62,3 & 62,9 & 63,2 & 27,7 & 59,6 & 60,5 & 61,6 & 25,5 & 65,3 & 69,8 & 69,0 & 32,9 \\
\hline 5006,3 & 33,8 & 63,2 & 61,2 & 61,2 & 28,1 & 59,6 & 60,8 & 60,8 & 26,6 & 65,4 & 68,8 & 68,0 & 33,6 \\
\hline 5009,4 & 34,9 & 61,0 & 62,5 & 60,2 & 26,3 & 60,8 & 59,6 & 61,4 & 25,7 & 67,1 & 68,3 & 67,9 & 32,8 \\
\hline 5012,5 & 34,4 & 62,6 & 62,8 & 62,3 & 28,2 & 62,6 & 60,4 & 60,5 & 26,8 & 67,6 & 68,4 & 69,8 & 34,2 \\
\hline 5015,6 & 34,5 & 63,9 & 63,1 & 63,5 & 29,0 & 62,7 & 60,6 & 62,2 & 27,4 & 67,8 & 68,0 & 69,9 & 34,1 \\
\hline 5018,8 & 34,8 & 62,9 & 63,2 & 64,2 & 28,6 & 60,8 & 61,9 & 62,9 & 27,0 & 66,4 & 69,4 & 67,4 & 32,9 \\
\hline 5021,9 & 34,1 & 62,3 & 63,6 & 64,5 & 29,3 & 61,4 & 62,3 & 62,8 & 28,0 & 65,7 & 71,0 & 67,7 & 34,0 \\
\hline 5025,0 & 37,6 & 62,8 & 64,0 & 64,5 & 26,2 & 60,5 & 62,2 & 61,6 & 23,9 & 65,4 & 70,8 & 69,3 & 31,0 \\
\hline 5028,1 & 37,4 & 63,5 & 63,5 & 63,8 & 26,2 & 60,8 & 62,2 & 62,6 & 24,5 & 65,6 & 69,9 & 68,7 & 30,6 \\
\hline 5031,3 & 36,8 & 62,6 & 64,6 & 63,3 & 26,7 & 61,3 & 62,2 & 64,2 & 25,7 & 65,3 & 69,2 & 67,2 & 30,4 \\
\hline 5034,4 & 36,5 & 62,8 & 64,3 & 63,0 & 26,8 & 59,8 & 62,2 & 64,2 & 25,5 & 64,6 & 68,6 & 68,9 & 30,8 \\
\hline 5037,5 & 36,4 & 62,4 & 65,5 & 62,1 & 27,0 & 61,3 & 61,3 & 63,8 & 25,8 & 64,8 & 68,9 & 67,2 & 30,6 \\
\hline 5040,6 & 36,3 & 62,0 & 65,2 & 62,8 & 27,1 & 61,7 & 61,1 & 64,2 & 26,1 & 64,6 & 67,8 & 66,0 & 29,9 \\
\hline 5043,8 & 34,4 & 61,2 & 62,0 & 61,6 & 27,2 & 62,3 & 62,3 & 63,5 & 28,3 & 64,7 & 66,8 & 66,0 & 31,5 \\
\hline 5046,9 & 33,5 & 61,1 & 60,1 & 60,0 & 26,9 & 62,3 & 62,9 & 62,3 & 29,0 & 65,7 & 67,7 & 66,3 & 33,1 \\
\hline 5050,0 & 33,1 & 60,5 & 62,4 & 58,9 & 27,5 & 61,3 & 61,5 & 62,5 & 28,7 & 65,8 & 68,7 & 66,1 & 33,8 \\
\hline 19928,1 & 15,0 & 46,7 & 49,5 & 47,5 & 32,9 & 54,1 & 55,3 & 55,3 & 39,9 & 51,4 & 48,3 & 49,7 & 34,8 \\
\hline 19931,3 & 14,5 & 48,2 & 49,8 & 48,0 & 34,2 & 53,3 & 55,2 & 54,9 & 40,0 & 52,3 & 46,9 & 49,1 & 34,9 \\
\hline 19934,4 & 14,6 & 48,4 & 48,7 & 48,2 & 33,8 & 53,9 & 54,6 & 53,9 & 39,5 & 52,5 & 47,8 & 48,6 & 35,0 \\
\hline 19937,5 & 15,8 & 48,5 & 49,0 & 48,7 & 33,0 & 54,1 & 53,7 & 53,2 & 37,9 & 52,1 & 47,8 & 49,0 & 33,9 \\
\hline 19940,6 & 15,2 & 48,0 & 48,8 & 47,9 & 33,1 & 54,3 & 54,4 & 53,9 & 39,0 & 52,4 & 47,9 & 49,2 & 34,7 \\
\hline 19943,8 & 15,2 & 47,8 & 48,9 & 47,7 & 33,0 & 54,8 & 54,3 & 54,4 & 39,3 & 52,6 & 47,6 & 49,7 & 34,8 \\
\hline 19946,9 & 15,4 & 47,5 & 48,2 & 47,4 & 32,3 & 54,6 & 54,6 & 54,6 & 39,2 & 52,9 & 47,5 & 48,9 & 34,3 \\
\hline 19950,0 & 14,6 & 48,5 & 48,9 & 47,7 & 33,8 & 53,3 & 53,5 & 53,5 & 38,9 & 53,1 & 47,3 & 48,8 & 35,2 \\
\hline 19953,1 & 14,1 & 49,2 & 48,1 & 47,6 & 34,2 & 54,8 & 53,3 & 54,8 & 40,2 & 53,3 & 48,6 & 49,3 & 36,3 \\
\hline 19956,3 & 15,0 & 49,5 & 48,2 & 46,8 & 33,2 & 54,2 & 53,7 & 55,3 & 39,4 & 52,8 & 49,3 & 50,1 & 35,7 \\
\hline 19959,4 & 14,0 & 46,7 & 48,4 & 48,3 & 33,9 & 53,4 & 52,5 & 53,9 & 39,3 & 53,0 & 49,4 & 49,7 & 36,8 \\
\hline 19962,5 & 13,9 & 47,1 & 48,7 & 49,3 & 34,4 & 52,8 & 54,0 & 55,2 & 40,1 & 52,5 & 48,7 & 50,0 & 36,4 \\
\hline 19965,6 & 15,0 & 47,4 & 48,1 & 49,3 & 33,3 & 53,6 & 54,8 & 55,4 & 39,6 & 51,6 & 48,1 & 51,5 & 35,4 \\
\hline 19968,8 & 14,6 & 47,3 & 47,9 & 48,0 & 33,1 & 54,8 & 54,7 & 54,9 & 40,2 & 51,9 & 48,7 & 50,5 & 35,7 \\
\hline 19971,9 & 14,9 & 47,0 & 48,0 & 48,3 & 32,8 & 55,9 & 54,0 & 53,8 & 39,6 & 51,3 & 47,9 & 49,8 & 34,8 \\
\hline 19975,0 & 15,1 & 47,7 & 48,0 & 47,8 & 32,8 & 55,2 & 53,8 & 53,8 & 39,2 & 52,0 & 47,9 & 48,7 & 34,5 \\
\hline 19978,1 & 15,2 & 46,7 & 49,1 & 46,8 & 32,3 & 55,0 & 54,7 & 53,9 & 39,3 & 52,1 & 47,7 & 48,7 & 34,3 \\
\hline 19981,3 & 14,5 & 45,9 & 49,7 & 47,3 & 33,1 & 54,7 & 54,5 & 53,8 & 39,8 & 51,7 & 48,1 & 49,4 & 35,2 \\
\hline 19984,4 & 16,0 & 48,3 & 48,3 & 46,1 & 31,6 & 53,9 & 52,9 & 53,6 & 37,5 & 51,2 & 48,2 & 49,9 & 33,8 \\
\hline 19987,5 & 16,6 & 47,2 & 48,5 & 46,9 & 30,9 & 53,6 & 54,2 & 54,0 & 37,3 & 52,0 & 47,8 & 50,0 & 33,3 \\
\hline 19990,6 & 16,0 & 47,6 & 48,9 & 48,1 & 32,2 & 53,6 & 54,3 & 54,2 & 38,0 & 52,1 & 49,1 & 49,7 & 34,3 \\
\hline 19993,8 & 15,4 & 47,9 & 48,8 & 48,6 & 33,1 & 54,6 & 54,5 & 54,3 & 39,1 & 52,3 & 49,1 & 50,2 & 35,2 \\
\hline 19996,9 & 15,5 & 48,6 & 48,4 & 47,6 & 32,7 & 54,3 & 54,6 & 53,0 & 38,5 & 53,3 & 50,4 & 50,3 & 35,8 \\
\hline 20000,0 & 15,6 & 48,1 & 48,7 & 48,1 & 32,7 & 53,7 & 54,4 & 54,1 & 38,5 & 52,6 & 49,2 & 51,4 & 35,5 \\
\hline
\end{tabular}




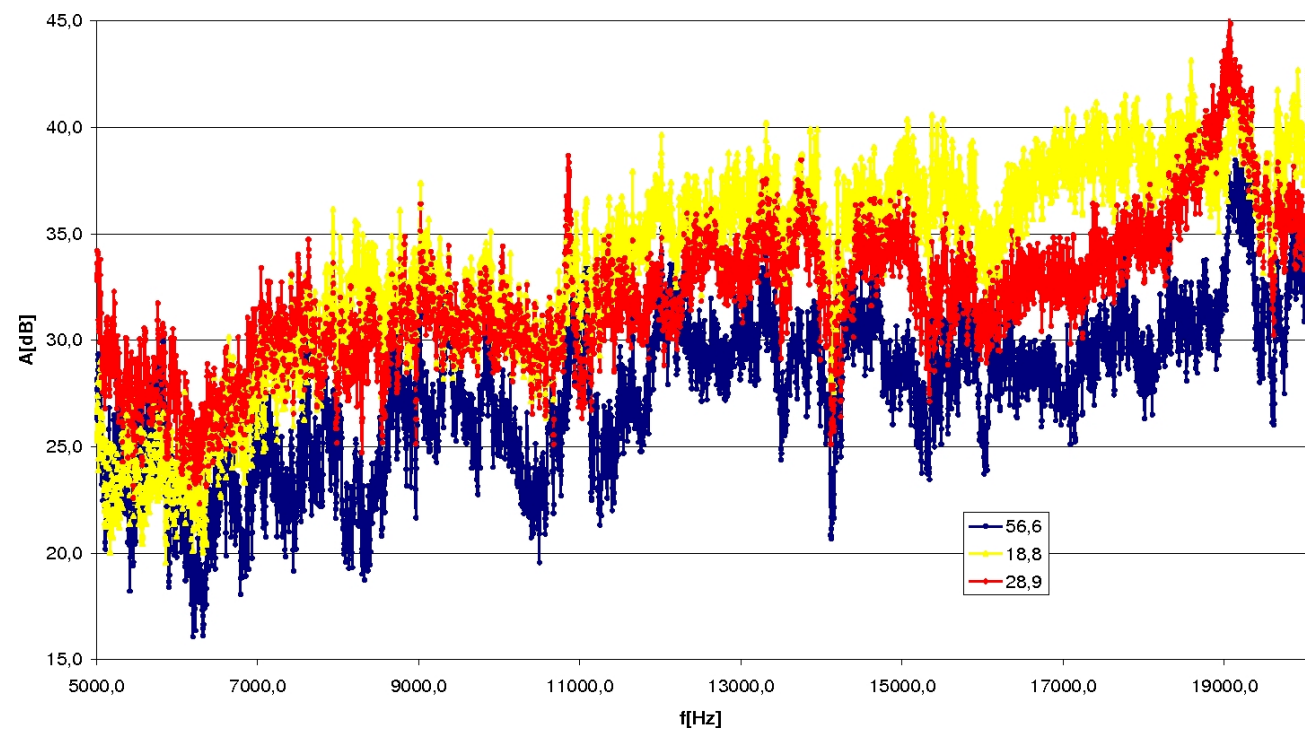

Rys 5. Widmo akustyczne dla klocka P10 przy prędkości $60 \mathrm{~km} / \mathrm{h}$

\section{Model numeryczny}

Rozpatrywany model numeryczny stworzono w programie Abaqus. Jest to końcowa wersja modelu po licznych modyfikacjach. W celu odzwierciedlenia warunków stanowiskowych przyjęto geometrię koła i klocka zgodne z dostępną dokumentacją [1]. Widok pary ciernej koło-klocek przedstawiono na rys.6.

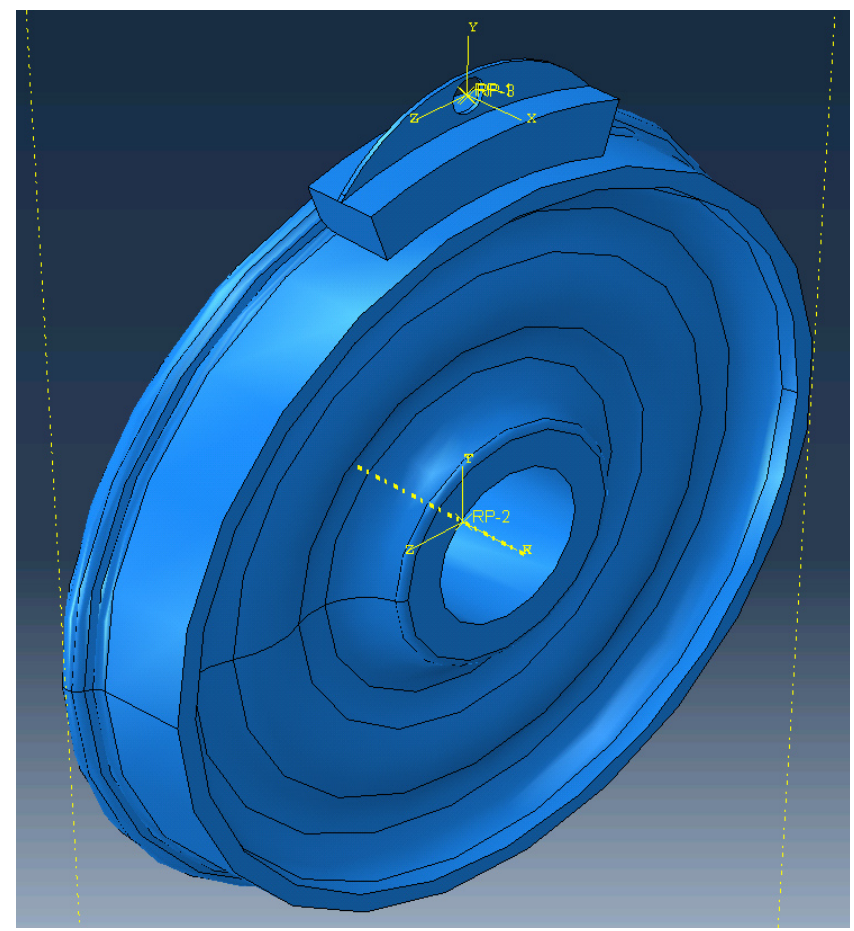

Rys. 6. Widok ogólny układu (klocek o grubości 60mm)
Zarówno koło jak i klocek zamodelowano, jako ciała odkształcalne sprężyście.

\subsection{Warunki zamocowania}

Przyjęto, że miejscem zamocowania koła jest punkt RP-2 położony w jego geometrycznym środku, a jedynym dopuszczalnym ruchem jest obrót dookoła osi. Oddziaływanie tego punktu na pozostałe obszary koła zasymulowane zostało poprzez wprowadzenie więzów typu kinematycznego (Constraint)

W celu odwzorowania rzeczywistych warunków klocek zamontowano w obsadzie. Ze względu na stanowiskowe warunki zamocowania, sprężystość elementów i istniejące luzy obsada wykazuje zróżnicowane zależnie od wyboru kierunku sztywności, dlatego zastosowano połączenie typu przegubowego (Coupling - Bushing - polaczenie sprężyste) pomiędzy sztywno związanym $\mathrm{z}$ obsada punktem RP-1 a sztywno związanym ze środkiem koła punktem RP3.

Połączeniu temu nadano właściwości sprężyste poprzez zdefiniowanie jego sztywności translacyjnych i obrotowych $w$ trzech kierunkach. Wprowadzone sztywności zestawiono w Tabeli 3 zaś połączenie przedstawiono na rys. 7 .

\begin{tabular}{|c|c|c|c|}
\hline \multicolumn{2}{|c|}{$\begin{array}{c}\text { Sztywność translacyjna } \\
{[\mathrm{N} / \mathrm{mm}]}\end{array}$} & \multicolumn{2}{c|}{$\begin{array}{c}\text { Sztywność obrotowa } \\
{[\mathrm{Nmm} / \mathrm{rad}]}\end{array}$} \\
\hline Kierunek X & 10000 & Względem X & 100000 \\
\hline Kierunek Y & 100 & Względem Y & 1000000 \\
\hline Kierunek Z & 100000 & Względem Z & 1000000 \\
\hline
\end{tabular}




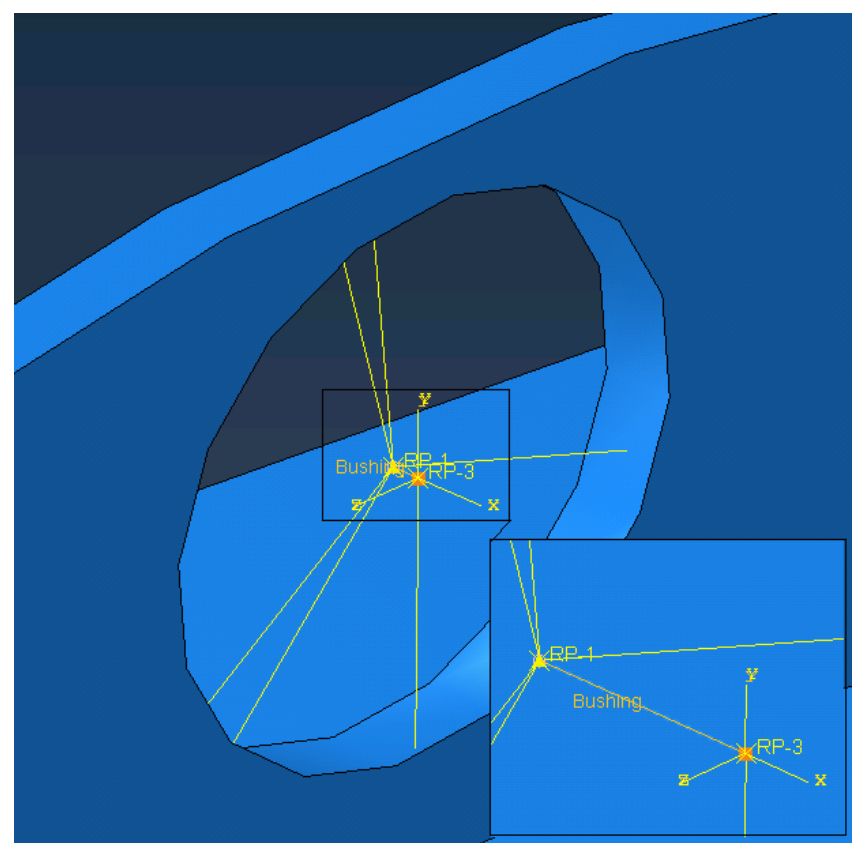

Rys. 7. Sposób zamocowania klocka

\subsection{Warunki kontaktu}

Oddziaływanie w strefie styku powierzchni koła i klocka zasymulowano wprowadzając opcję kontaktu ogólnego dostępną w Solverze Explicit programu Abacus. Współczynnik tarcia zdefiniowano jako stały 0,30 . Jako powierzchnię nadrzędną wskazano powierzchnię toczną koła a status powierzchni podrzędnej nadano powierzchni przylegania klocka (rys. 8).

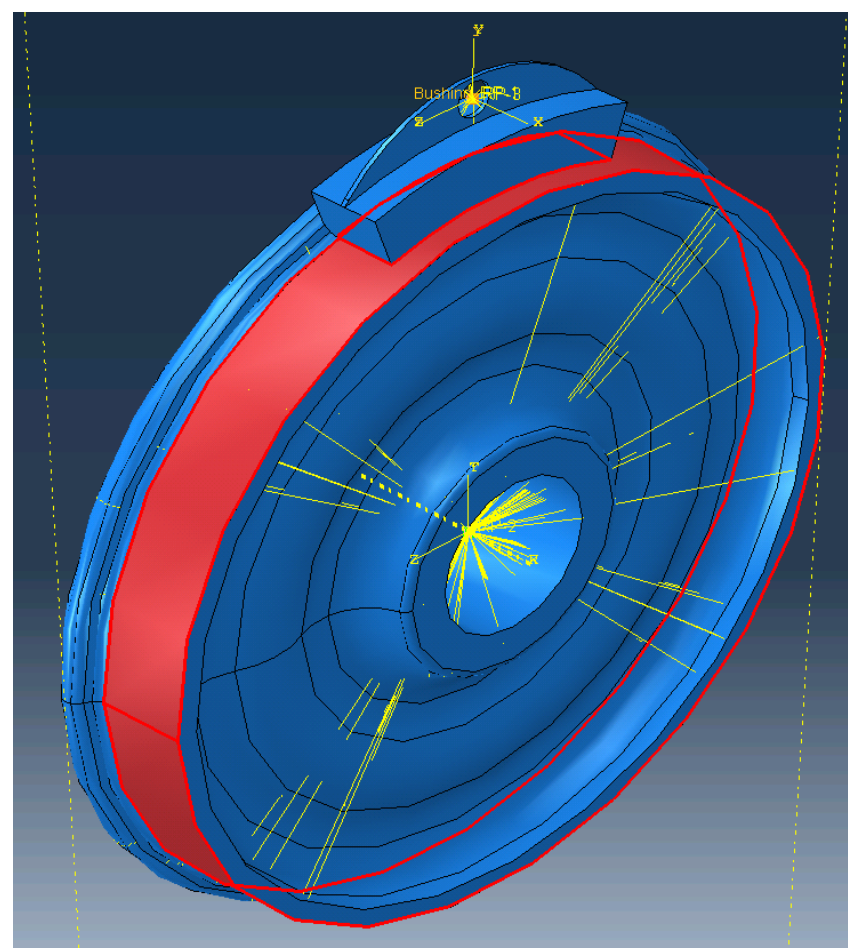

Rys. 8. Sposób określenia kontaktu pomiędzy powierzchnią koła i klocka

\subsection{Warunki ruchu i obciążenia}

Prędkość obrotową koła zadano w powiązanym $\mathrm{z}$ nim punkcie RP-2. Liniowy przyrost prędkości od wartości początkowej $0 \mathrm{~m} / \mathrm{s}$ do żądanej wartości końcowej osiagnięto posługując się opcją Amplitude w kroku prędkość.

Obciążenie pochodzące od siły nacisku zadano w postaci siły skupionej działającej w punkcie RP-1, która dzięki wprowadzonemu powiązaniu sprężystemu symuluje oddziaływanie sworznia na obsadę podczas docisku.

Bezwładność mas wirujących uwzględniono wprowadzając masę skupioną 10t w punkcie RP-2.

Kolejność oraz czas poszczególnych kroków ilustruje Tabela 4

Kolejność kroków procedury obliczeniowej Tabela 4

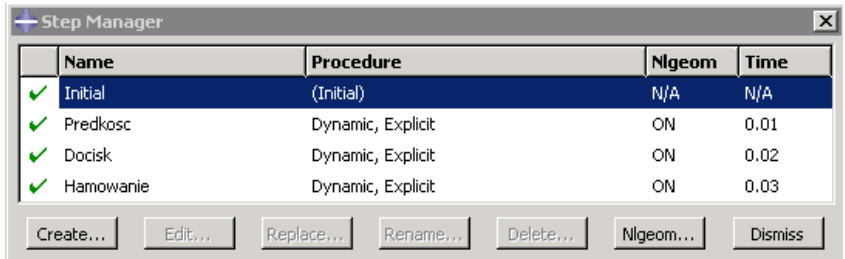

\subsection{Podział modelu na elementy skończone}

Zarówno do podziału klocka jak i koła zastosowano elementy czworo-ścienne typu Tet. Wielkość „oczka siatki” na kole zadano, jako $50 \mathrm{~mm}$ zaś na klocku, jako $10 \mathrm{~mm}$, w obu przypadkach typ elementu określono, jako Explicit. Podział modelu na elementy skończone przedstawiono na rys 9.

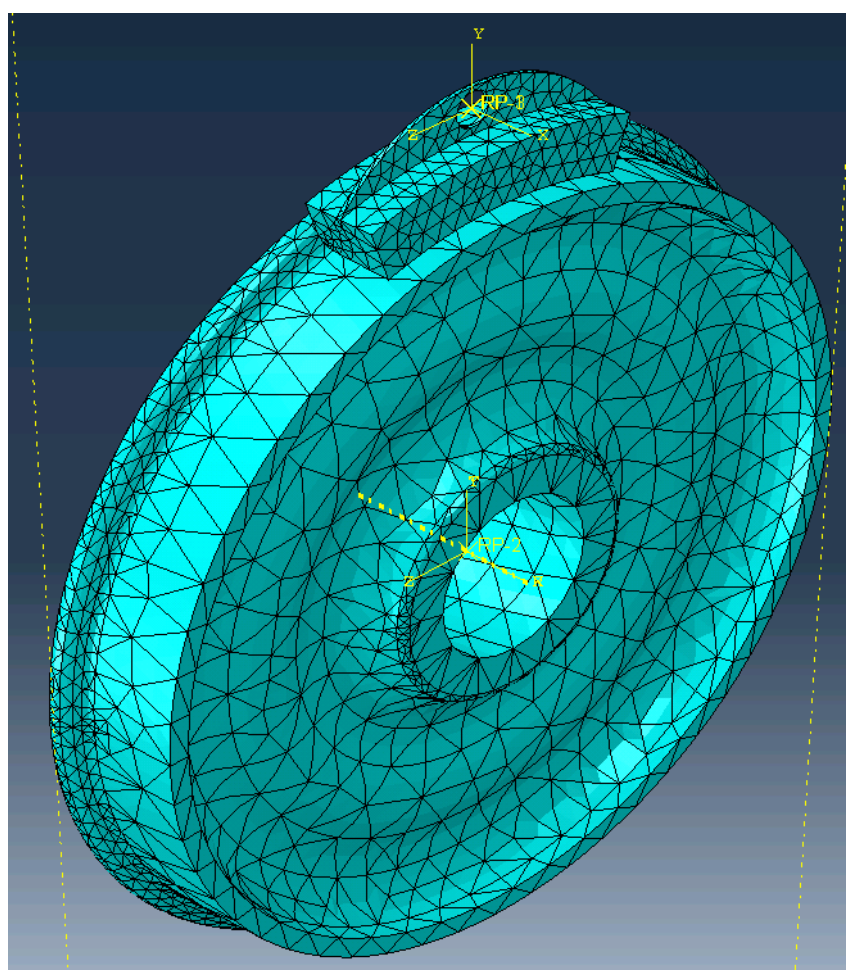

Rys. 9. Podział modelu na elementy skończone 


\subsection{Uzyskane wyniki}

Rozważaniom numerycznym poddano dwie skrajne grubości klocka $60 \mathrm{~mm}$ i $15 \mathrm{~mm}$ odpowiadające stanowi początkowemu eksploatacji i skrajnemu zużyciu. Porównaniu i ocenie poddano rozkłady spektralne częstotliwości drgań w kierunku stycznym U3 do powierzchni klocka, wartości naprężeń i odkształceń oraz uśrednionych wychyleń węzłów na krawędzi wychodzącej klocka (rys. 10). Ze względu na znane z praktyki zjawisko wzrostu częstotliwości emitowanej fali akustycznej w przypadku dohamowywania tj. dla niskich prędkości, zdecydowano się przeprowadzić analizę dla prędkości kątowych wynoszących odpowiednio $0,1 \mathrm{rad} / \mathrm{s}, 5 \mathrm{rad} / \mathrm{s}, 10 \mathrm{rad} / \mathrm{s}$ i $20 \mathrm{rad} / \mathrm{s}$. Osiagnięte wyniki zestawiono na rys. 11, 12, 13 i 14.

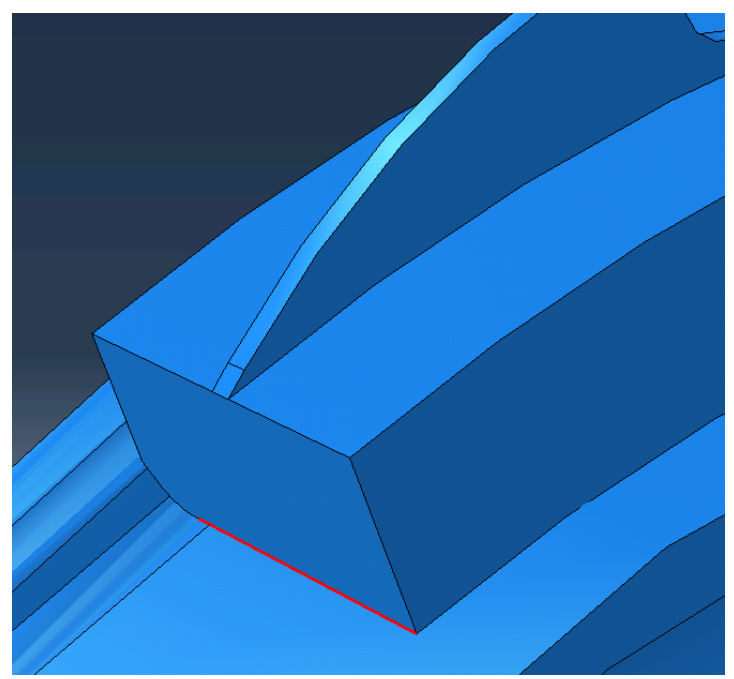

Rys. 10. Krawędź ,atakująca” klocka, z której odczytywane są wyniki

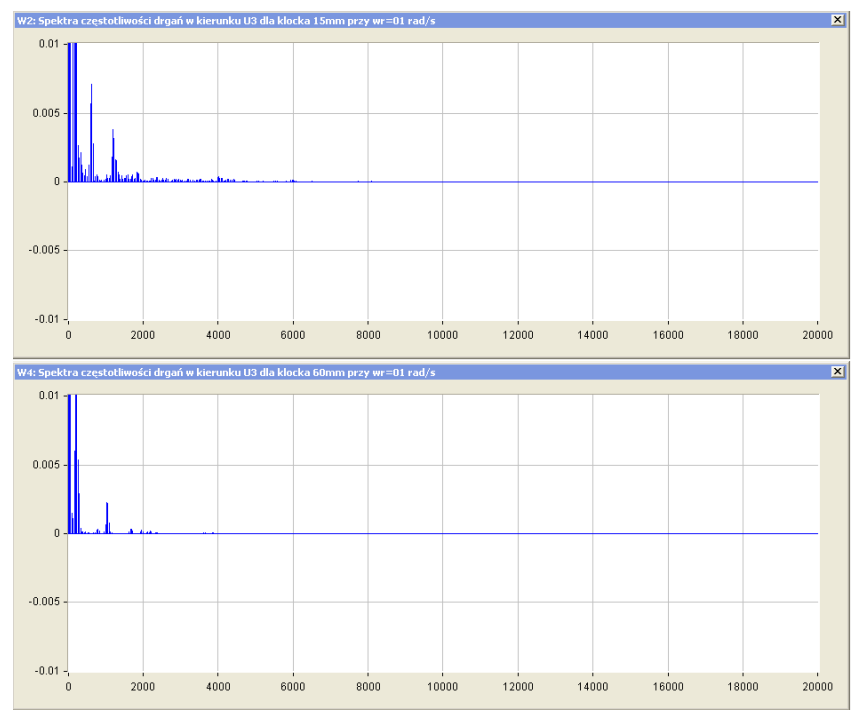

Rys. 11. Spektra częstotliwości drgań krawędzi klocka w kierunku U3 (grubości klocka 60mm i 15mm) w zakresie częstotliwości od $0 \mathrm{~Hz}$ do $20 \mathrm{kHz}$ przy prędkości obrotowej koła $0,1 \mathrm{rad} / \mathrm{s}$

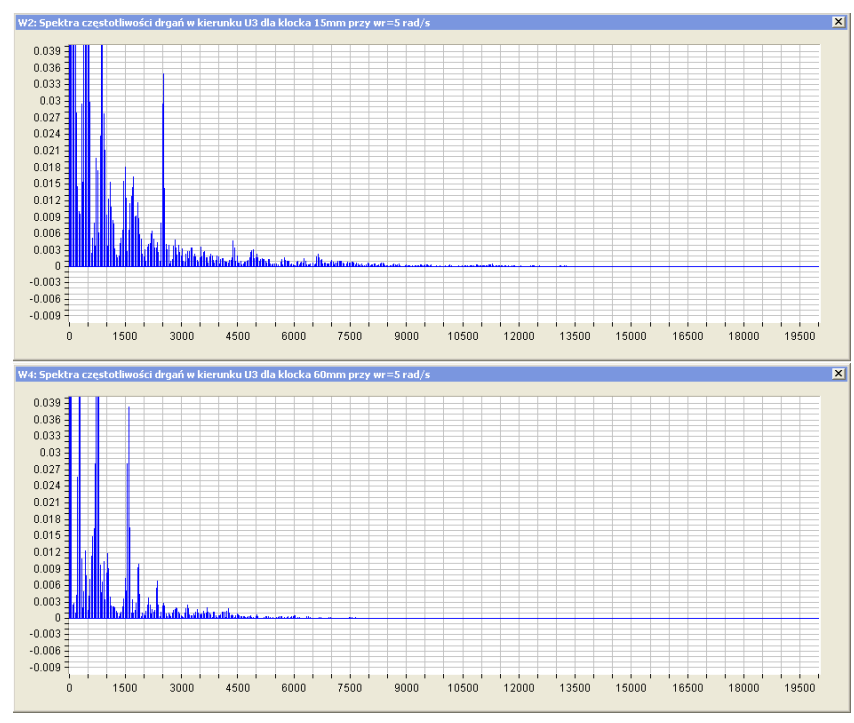

Rys. 12. Spektra częstotliwości drgań krawędzi klocka w kierunku U3 (grubości $60 \mathrm{~mm}$ i $15 \mathrm{~mm}$ ) w zakresie częstotliwości od $0 \mathrm{~Hz}$ do $20 \mathrm{kHz}$ przy prędkości obrotowej koła $5 \mathrm{rad} / \mathrm{s}$

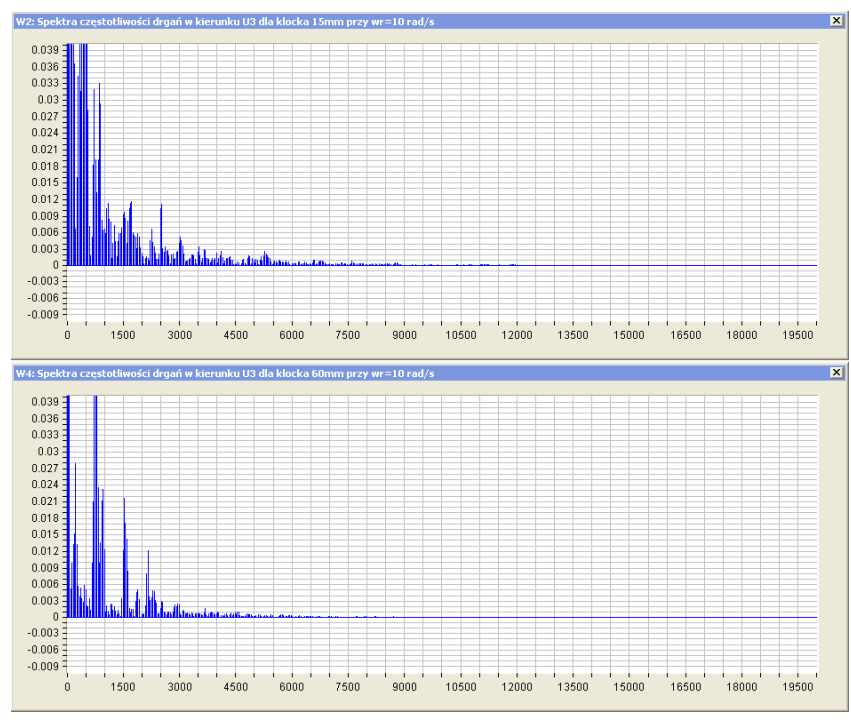

Rys. 13. Spektra częstotliwości drgań krawędzi klocka w kierunku U3 (grubości $60 \mathrm{~mm}$ i $15 \mathrm{~mm}$ ) w zakresie częstotliwości od $0 \mathrm{~Hz}$ do $20 \mathrm{kHz}$ przy prędkości obrotowej koła $10 \mathrm{rad} / \mathrm{s}$

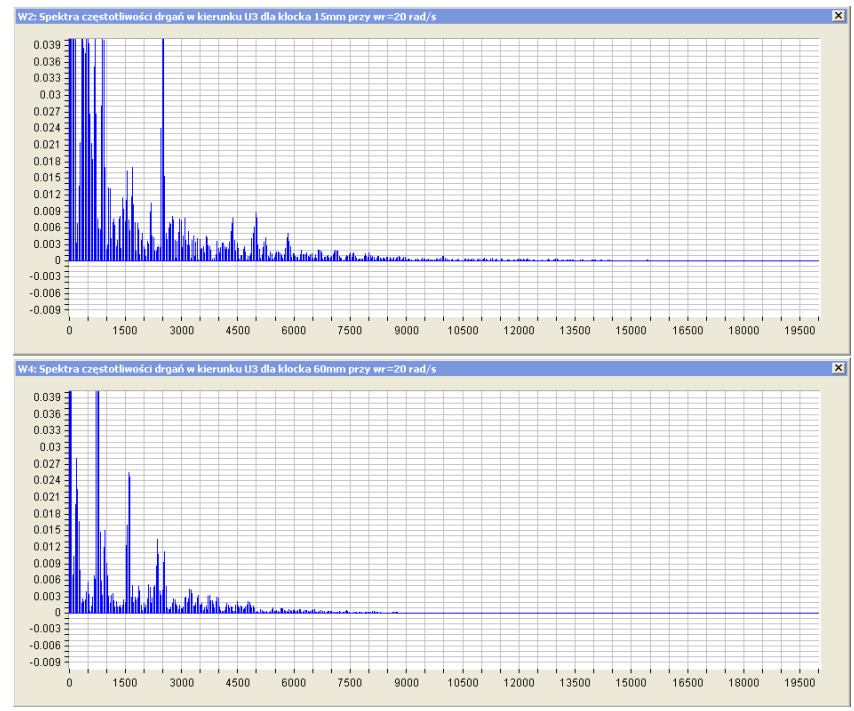

Rys. 14. Spektra częstotliwości drgań krawędzi klocka w kierunku U3 (grubości $60 \mathrm{~mm} \mathrm{i} 15 \mathrm{~mm}$ ) w zakresie częstotliwości od $0 \mathrm{~Hz}$ do $20 \mathrm{kHz}$ przy prędkości obrotowej koła $20 \mathrm{rad} / \mathrm{s}$. 


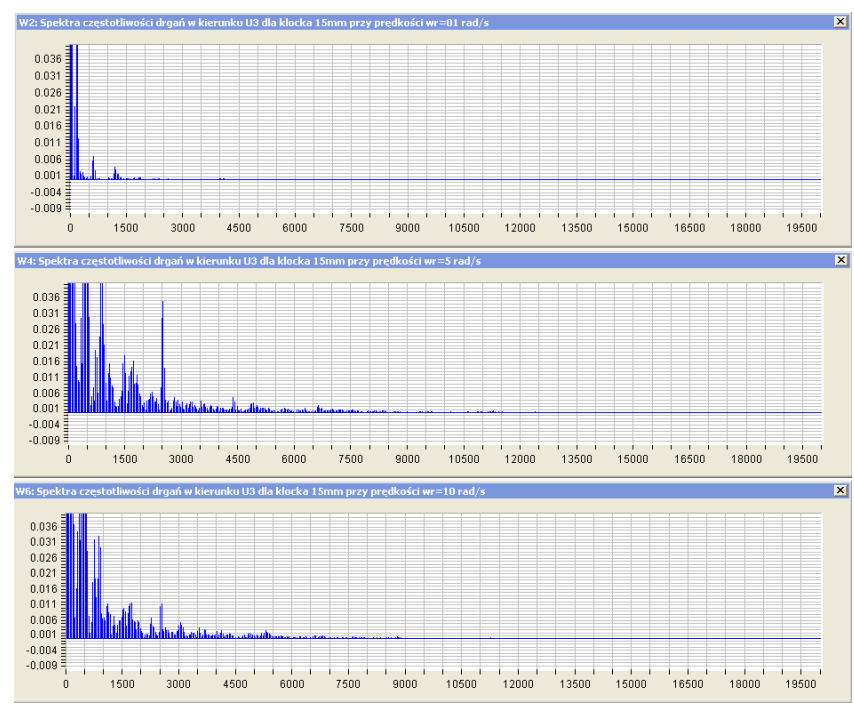

Rys. 15. Spektra częstotliwości drgań klocka o grubości $15 \mathrm{~mm}$ przy różnych prędkościach obrotowych koła.

Rozkłady naprężeń zredukowanych wg Misesa powstałych dla klocka nowego i zużytego przedstawiono na rysunkach 16 i 17.

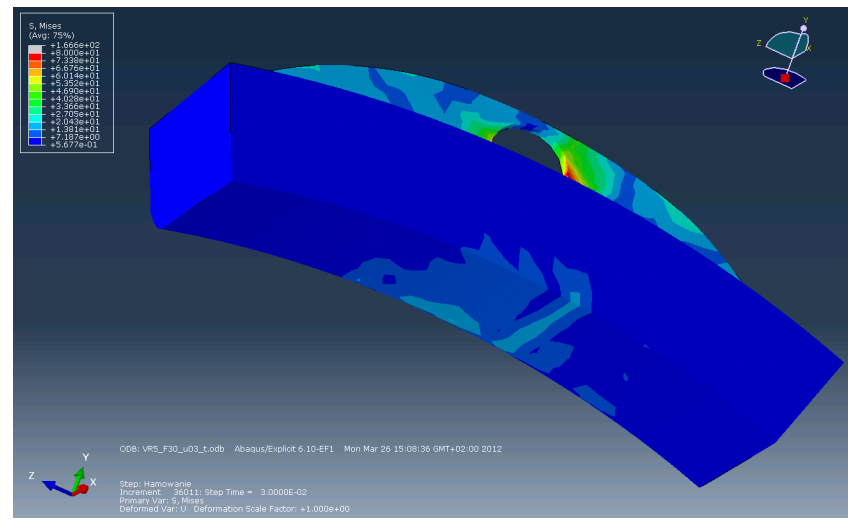

Rys. 16. Naprężenia wg Misesa dla klocka o grubości $60 \mathrm{~mm}$.

W celu skonfrontowania uzyskanych wyników z eksperymentem porównano wyznaczone numerycznie spektra częstotliwości drgań węzłów krawędzi klocka dla prędkości 40 i $80 \mathrm{~km} / \mathrm{h}$ z spektrami wyznaczonymi eksperymentalnie (na stanowisku 12SB w IPS Tabor).

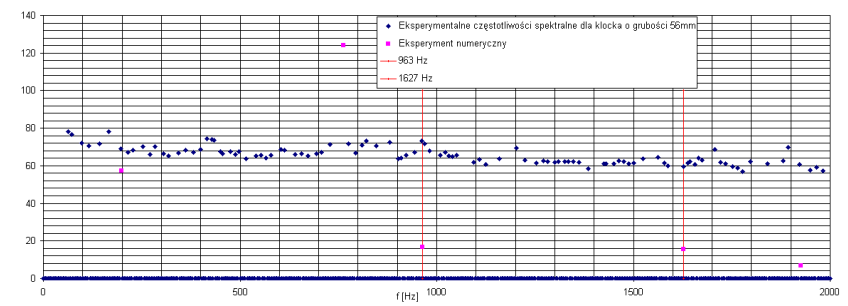

Rys. 18. Zestawienie częstotliwości spektralnych dla prędkości 40 $\mathrm{km} / \mathrm{h}$

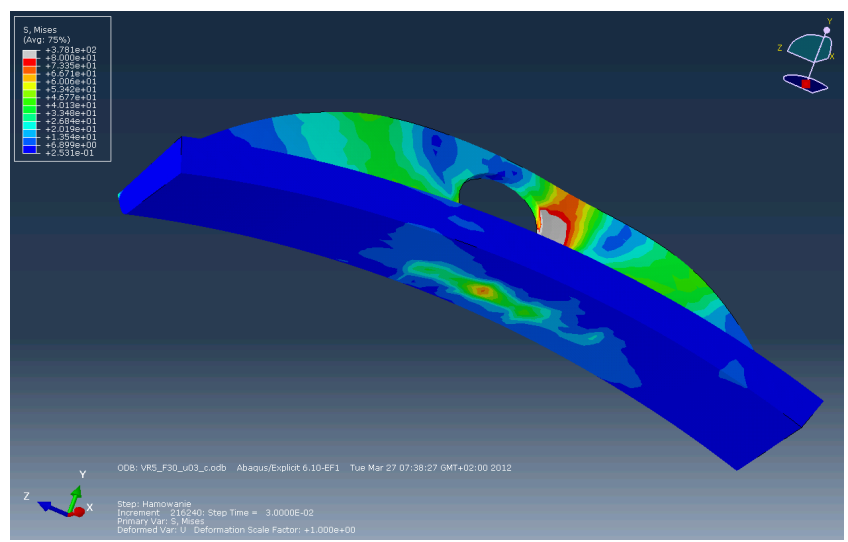

Rys. 17. Naprężenia wg Misesa dla klocka o grubości $15 \mathrm{~mm}$.

Wyznaczone teoretycznie wartości częstotliwości spektralnych drgań krawędzi klocka dla prędkości 40 $\mathrm{km} / \mathrm{h}$ i $80 \mathrm{~km} / \mathrm{h}$ z wynikami eksperymentalnymi przedstawiono na rys. 18 i 19.
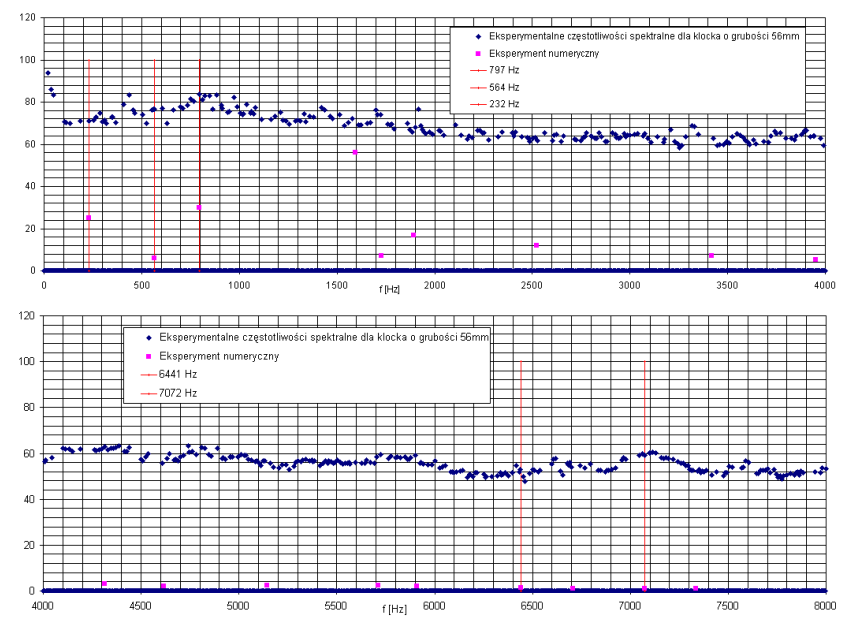

Rys. 19. Zestawienie częstotliwości spektralnych dla prędkości 80 $\mathrm{km} / \mathrm{h}$

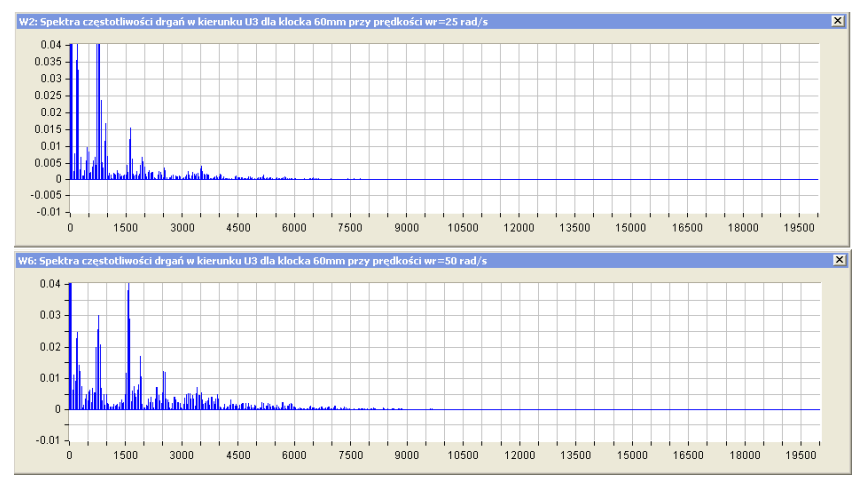

Rys. 20. Częstotliwości spektralne drgań dla prędkości $\mathrm{w}_{\mathrm{r}}=25 \mathrm{rad} / \mathrm{s}$ i $50 \mathrm{rad} / \mathrm{s}$.

\section{Podsumowanie}

Otrzymane wyniki pozwalają wnioskować, że występuje zróżnicowanie w zakresie spektrów częstotliwości drgań węzłów w zależności od grubości klocka. 
Zmniejszenie grubości klocka doprowadza do zwiększenia zakresu spektrów częstotliwości drgań zwłaszcza dla prędkości kątowej obrotu koła wynoszącej $5 \mathrm{rad} / \mathrm{s}(8 \mathrm{~km} / \mathrm{h})$, oraz do wzrostu naprężeń $\mathrm{w}$ obrębie klocka, co ilustruja przedstawione wykresy. Odczytane z wykresów częstotliwości spektralne dla wybranych prędkości obrotowych koła i dwóch skrajnych grubości klocka zestawiono w Tabeli 5.

Częstotliwości spektralne

\begin{tabular}{|c|c|c|}
\hline $\begin{array}{c}\text { Prędkość } \\
\text { obrotowa } \\
\text { koła } \\
{[\mathrm{rad} / \mathrm{s}]}\end{array}$ & $\begin{array}{c}\text { Klocek } \\
15 \mathrm{~mm} \\
{[\mathrm{~Hz}]}\end{array}$ & $\begin{array}{c}\text { Klocek } \\
60 \mathrm{~mm} \\
{[\mathrm{~Hz}]}\end{array}$ \\
\hline 0,1 & $\begin{array}{l}66,166,465,630,764 \\
1195,1826\end{array}$ & $\begin{array}{l}66,199,797 \\
1029,1693\end{array}$ \\
\hline 5 & $\begin{array}{l}99,431,896 \\
1096,1494,1726,1826 \\
2224,2523,2822,2922 \\
3519,3619,3784 \\
4117,4382,4914 \\
5013,5741 \\
6275,6640 \\
7005,7171\end{array}$ & $\begin{array}{l}66,133,266,432,763 \\
1029,1594,1859 \\
2125,2357,2523,2855 \\
3154,3420,3685 \\
4117,4250,4482\end{array}$ \\
\hline 10 & $\begin{array}{l}33,66,133,332,398,49 \\
8,730,863 \\
1096,1262,1527,1726 \\
2258,2523,2623,2822 \\
3021,3320,3519,3652, \\
3984 \\
4117,4349,4847,4947 \\
5046,5278 \\
6574 \\
7603\end{array}$ & $\begin{array}{l}33,232,465,764,963 \\
1527,1892 \\
2158,2290,2523,2956 \\
3685,3851 \\
4017,4383,4548\end{array}$ \\
\hline
\end{tabular}

Stablicowane częstotliwości drgań węzłów klocka mogą, więc generować falę akustyczną mieszczącą się w granicach słyszalności dla człowieka.

Przeprowadzone badania numeryczne i stacjonarne dostarczają informację na temat różnic występujących w zakresie drgań klocka o dwóch skrajnych grubościach.

Stąd ze względu na złożoność zjawiska i pełne uwzględnienie rzeczywistych warunków pracy, wskazana jest dalsza analiza eksperymentalna (stanowiskowa) rozważanego procesu $\mathrm{z}$ wykorzystaniem precyzyjnej aparatury pomiarowej (np. mikrofony kierunkowe o zakresie pomiarowym do $70 \mathrm{kH}$ ) na stanowisku pomiarowym oraz podczas badań poligonowych. Badania te powinny być przeprowadzone $\mathrm{z}$ zastosowaniem izolowanym akustycznie tłem.
Wyniki tych badań pozwolą na dokładniejsze i bardziej szczegółowe określenie częstotliwości i amplitud widma akustycznego charakterystycznego dla różnych grubości klocka hamulcowego.

Umożliwi to diagnostykę stanu zużycia klocków podczas bieżącej eksploatacji (np. przejazd pociągu z określoną prędkością przez punkt pomiarowy). Otrzymane w czasie takiego pomiaru wyniki mogłyby być na bieżąco analizowane i porównywane $\mathrm{z}$ wcześniej opracowanym wzorcem „widmo/grubość”, co pozwoliłoby na wskazanie granicznie zużytych klocków przeznaczonych do natychmiastowej wymiany na poszczególnych pojazdach (docelowo z dokładnością do osi). Możliwe byłoby także określenie przewidzianego zużycia zależnego od przebiegu.

\section{Literatura:}

[1] Abd Rahim Abu Bakar, Huajiang Ouyang, "Prediction of disc brake contact pressure distributions by finite element analysis, "Jurnal Teknologi, 43(A). Dis. 2005, 21-36.

[2] Abd Rahim Abu Bakar, Mohd Kameil Abdul Hamid, Afandi Dzakaira, Badri Abdul Ghani, Maziah Mohamad, "Stability analysis of disc brake squeal considering temperature effect", Jurnal Mekanikal, December 2006, No. 22, 2638.

[3] F. Massi, L. Baillet, "Numerical analysis of squeal instability"

[4] A. R. A. Bakar, H. Ouyang, D. Titeica, M. K. A. Hamid, "Modelling and simulation of disc brake contact analysis and squeal", Seminar on Advances in Malaysian Noise Vibration and Comfort, 17-18 May 2005. 